Migration Studies - Review of Polish Diaspora nr 3 (177)/2020, http://www.ejournals.eu/Studia-Migracyjne/ DOI: 10.4467/25444972SMPP.20.029.12593

\title{
Coercion, Compulsion, Forced Emigrations. Experiences of Polish Artists during the Martial Law in Poland
}

\author{
TOMASZ FERENC 1 \\ ORCID: 0000-0003-0748-889X \\ Faculty of Economics and Sociology \\ University of Łódź: Centre of Migration Studies
}

\begin{abstract}
A sociological look at artists' biographies makes one reflect on their increased mobility. Purposes and reasons of the artists' migratory journeys are various, they have a different character and their effects also vary. The article based on the narratives of the Polish artists shows three variants of making decisions to emigrate from Poland following the imposition of the martial law in December of 1981. The purpose of the article is also an attempt to modify the dominant definitions of forced emigration by extending it to the aspect of internal coercion generating a strong push impulse. This internal factor seems to be very important in the cases analysed in the article. The biographical interview method allows to indicate that, apart from external coercion, various entanglements of circumstances and trajectories are revealed, which in some cases lead to the decision to leave the home country.
\end{abstract}

Keywords: émigré artists, martial law, trajectory, forced migration, compulsion.

Artists constitute an extremely diverse professional and social category. They make a group which unambiguous and precise definition brings some difficulties. Stating that artists are people who deal with art in a way that indicates proficiency and professionalism does not allow them to be clearly distinguished from experienced amateurs or enthusiasts, often presenting a high level of their skills and competences. Similarly, artistic education from a sociological point of view does not allow for a clear separation of artists from other professionals. Having these and other dilemmas in

\footnotetext{
1 Contact: tomasz.ferenc@uni.lodz.pl
} 
mind while establishing a coherent semantic field, Marian Golka proposed a definition indicating that the artist is a person engaged in creative activities of an individual character, indicating proficiency, and at the same time proving the commitment of talent, imagination and other personality traits. This activity performs a specific social function, accepted by the community as a result of the demand for specific values that the artist can offer (Golka 2008: 77). As Nathalie Heinich notes, this professional category is specific because it consists of both actual (confirmed by statistics) features and a number of social perceptions that we create about artists (Heinich 2007: 93). These artistic mythologies are produced and sustained by both the creators themselves and the recipients, this way constituting an important element of the social reception of the artist's role. In the following text, attention will be focused on professional artists who have occupied or still occupy a significant position in the world of art. The text analyses the fate of immigrant artists who left the country or decided to stay outside Poland in the result of the imposition of martial law in December of 1981. The text will propose a way of understanding forced emigration deviating from those definitions in which the direct reason for leaving the place of residence is a direct coercion or threat to life. The stories of emigrant artists for whom the introduction of the martial law turned out to be a biographical turning point causing modification or an entire change of life plans will be analysed. At the same time, it is worth to emphasize that the emigration of artists during the martial law, in many cases extremely dramatic, falls under the broader issue of the increased spatial mobility of this professional group, which deserves paying some attention at the outset. Thus, the text opens with a short presentation of several significant theoretical: social and historical issues related to the discussed question, while its empirical part will describe, among others research procedures and sampling criteria.

\section{Increased voluntary and forced mobility of the artists}

Significant periods of migration are present in the biographies of many artists. Starting with the great Renaissance masters like Leonardo da Vinci and Michelangelo, through baroque geniuses such as Caravaggio, Velazquez or Canaletto, classicist painters Nicolas Poussin, Jacques Luis David, and French post-expressionists like Paul Gauguin or Vincent van Gogh; in all these biographies we find essential and lasting biographical consequences of migration. Further examples of this phenomenon can be multiplied, providing names of writers, musicians, dancers, photographers, filmmakers and representatives of all other creative professions. Many of these migrations we voluntary, but a major proportion resulted from direct coercion. Focusing on the biographies of Polish artists, it is impossible not to notice that there were many such forced migrations of permanent or periodic nature. From the times when Poland, in the result of partitions, disappeared from the map of Europe for over a hundred 


\section{SM̂PP}

years, successive cohorts of the Polish intelligentsia and artists have experienced various forms of persecution. Each national uprising ended in an intensive emigration movement. The fall of the November Uprising in 1831 also caused an exodus of the greatest Polish artists of that time or forced them to continue emigration. These artists were, among others: Adam Mickiewicz, Juliusz Słowacki, Fryderyk Chopin, and Zygmunt Krasiński. The history of Polish art is inseparable from the constant voluntary or forced migration of artists. Many of the most outstanding works found in the Polish canon, and often also of world culture, were created outside of Poland. The artists compared to other professional groups are characterized by an increased readiness to undertake migrations, both domestic and external, short and longterm, permanent and circular. Their spatial mobility results from many social, psychological, political and economic factors. It is often a consequence of the specificity of the artistic education process, the nature of the orders carried out, the dynamics of seeking and receiving orders, and employment opportunities. The artists, even those creating individually, are connected with artistic environments, often of supralocal nature, and in some cases also global. Interaction with such environments repeatedly results in permanent or periodic migration. In various urban centres such as Rome and Paris in the nineteenth century or Munich and Vienna at the beginning of the twentieth century there were significant artistic circles radiating throughout Europe (Golka 2008: 148). They attracted crowds of artists desiring to find themselves in one of such cultural centres. Paris plays a special role in the history of Polish artistic emigration. In addition to those who migrated forcibly, those who wanted to be in the centre of European culture also travelled to the French capital. "The desire for success and recognition was not the only factor prompting Poles to travel to the Seine. One can even risk the hypothesis that they were fascinated by the rather lively and invigorating intellectual and artistic atmosphere of this extraordinary city, before they even found it" (Bobrowska-Jakubowska 2004: 43). It was simply good to spend some time in Paris and, if possible, exhibit some work, too. Jan Matejko, Stanisław Wyspiański, Józef Chełmoński, Wojciech Kossak and Jan Styka all did so. At the turn of the nineteenth and twentieth centuries, Paris was an important Polish intellectual centre and artistic colony. Over time other European metropolises started playing that role for Poles. An important place on the migratory routes of the Polish artists was and still is the capital of Great Britain. Adam Supruniuk emphasizes that between the end of the nineteenth century and the year 2000, eight hundred active Polish artists can be identified in the British Isles. The author puts forward the thesis that "in terms of numbers and durability, the Polish artistic community in Great Britain in the twentieth century was the largest outside Poland and the most diverse" (2006: 5). Over time, Berlin and New York became significant centres for the Polish artistic community. Global cities attract artists from around the world, generating a constant migration movement among them. The complex of psychic features facilitating the decision on permanent or temporary change of residence is also important 
in the search for the reasons for emigration. In many interviews gathered, the topic of cultural competences acquired in the course of socialization revealed potential for readiness to leave and education of personality with a predisposition to adopt a cosmopolitan attitude. Yet another group of reasons for this increased mobility stems from the fact that the artists more often than representatives of other professional groups experience different forms of censorship and exclusion². It can be said that the lives of artists often become a kind of litmus test of political systems and a test of readiness of social systems to adopt actions different from accepted axionormative models. Very often, relations between artists and authorities take on a conflicting form, and often as a result of repression against the creators. Restrictions on the possibilities of free creative work, a growing sense of danger, various forms of persecution experienced by the artists and their families often lead to the decision to leave their home country. In many biographies of the Polish artists, the emigration they experienced was forced, which was usually influenced by one of four significant, chronologically consecutive historical events: the outbreak of World War II, the takeover of power by the communists after 1945, the anti-Semitic events of March 1968, and the consequences of the imposition of the martial law in 1981.

\section{Forced emigrations: external coercion, internal coercion}

Every form of emigration means temporary or permanent abandonment of the known social world and the need to adapt to different cultural, economic and political conditions. This type of experiences is associated with a longer or shorter duration of inconvenience, very often becoming trajectory. Each emigrant undergoes a phase of more or less distressing feelings of alienation. This is because everything that he knew until now, and which was the foundation of his "habitual thinking", as Alfred Schütz puts it, is interrupted. Nothing is obvious, there are no ready tips on how to proceed and interpret the world. "Therefore, the stranger approaching the new group is a newcomer in the full sense of the word. At best, he may be able to share the group's present and future in a process of vital and direct experience. However, in all respects he remains excluded from the past experiences of this group. From a group perspective, a stranger is a man without history" (Schütz 2008: 217). Every immigrant experiences the condition of strangeness. However, the trajectories of dealing with it and the consequences of this experience vary. Biographical work done by emigrants involves, among others, dealing with alienation. Overcoming alienation is gradual, processual and must be considered contextually, by taking into account historical, political, economic and cultural variables. However, this experi-

2 Report Cenzura, płeć, demokracja by Majewska E. and Nabokina A. on contemporary acts of violating the freedom of speech and act of artists reveals multiple examples of such abuse in East and Middle Europe. https://pl.boell.org/sites/default/files/raport_cenzura.pdf [Accessed: 14.02.2020] 
ence varies depending on many factors, to mention few like reasons for emigration, circumstances of departure, support received in the new place of residence, knowledge of the language and cultural realities of the host society. There are more factors, but the key one is whether the decision to leave one's own country was made voluntarily or as a result of coercion. In other words, does the individual become an emigrant either of his or her own volition or as a result of various processes forcing them to leave?

Forced emigration is a complex, multi-faceted phenomenon. The Oxford law handbook highlights six categories of this type of emigrants: 1. Refugees, people outside home country, who cannot return because of a 'well-founded fear of persecution on account of race, religion, nationality, membership in a particular social group, or political opinion. 2. Asylum seekers, i.e. people who have moved across an international border in search of protection but whose claim for refugee status is as yet undecided. 3. Internally Displaced Persons ('IDPs'): persons who have been forced (...) to leave their homes (...) in order to avoid the effects of armed conflict, situations of generalized violence, violations of human rights or natural or human-made disasters, and who have not crossed an internationally recognized state border'. 4. Development displaces: people compelled to move by large-scale development projects (dams, airports, mining, conservation parks). 5. Environmental and disaster displaces: people displaced by natural disasters (floods, volcanoes, landslides, earthquakes), environmental change deforestation, desertification, land degradation), and human-made disasters (industrial accidents, radioactivity, water pollution) and finally 6 . Trafficked persons: especially women and children, these are persons transported using violence, coercion, or by providing misleading information, in order to exploit them sexually or economically ${ }^{3}$. In the glossary published in 2018 by European Migration Network we find this definition of forced migration: "A migratory movement in which an element of coercion exists, including threats to life and livelihood, whether arising from natural or man-made causes (e.g. movements of refugees and internally displaced persons as well as people displaced by natural or environmental disasters, chemical or nuclear disasters, famine or development projects)."4 In turn glossary compiled by International Organization for Migration in short definition beside force and coercion, as main reason of forced migration points compulsion ${ }^{5}$. That third factor seems to be very important in the cases analysed in this text: internal coercion causing an irresistible desire to leave the country of origin, the conviction of losing control over one's own life, the impossibility of functioning normally under the martial law, a sense of the total lack of opportunities to develop an artistic career and last but not least, lack of faith in improving the economic situation. Objective premises,

\footnotetext{
3 https://www.researchgate.net/publication/317237153 Forced Migration [Accessed: 12.02.2020]

${ }^{4}$ https://ec.europa.eu/home-affairs/sites/homeaffairs/files/what-we-do/networks/european_migration_network/docs/interactive_glossary_6.0_final_version.pdf [Accessed: 12.02.2020]

${ }^{5}$ https://publications.iom.int/system/files/pdf/iml_34_glossary.pdf [Accessed: 12.02.2020]
} 
but also a subjective feeling of the need to leave may accompany the feeling of compulsion. Marek Czyżewski, writing about biographical vectors, proposes a bipolar diagram: rooting in history and rooting in a milieu. Rooting in history consists in situating one's own biographical processes in a macro-historical and macro-social perspective, which is typical for the elite. Rooting in the milieu is characterized by the placement of biographical processes in the micro-local plan (1996: 46). Czyżewski emphasizes that in the upper social strata, rooting in history and in milieu can overlap. It is often the case of artists who, reporting their fates, place them in the broader context of historical events. Cumulative historical and environmental factors led to the emergence of a large wave of emigration. Before attempting to analyse fragments of biographical stories of artists, it may be useful to briefly present the historical background.

\section{The martial law in brief}

A deepening economic crisis and a growing, increasingly active manifestation of public dissatisfaction with the communist authorities mark the turn of the 1970s and 1980s. Growing in strength and provided with great social support, the Solidarity Independent Self-Governing Trade Union organized numerous strikes during this period in which economic and political reforms were demanded. "For a variety of reasons then, a surge of strikes swept across the country beginning July. In some towns, such as Lublin, they reached the scale of a general strike. (...) The authorities took those developments extremely seriously, sometimes sending high-level ministers to hold talks" (Paczkowski, Byrne 2007:6). Those strikes reached other cities, among them Szczecin and Gdańsk, where strike committee was headed by Lech Wałęsa. The strike committees prepared lists of demands. "The first point of each was almost identical, calling for the creation of free trade unions independent of government" (2007: 7). Among those 21 demands presented in Gdańsk there was one particularly important: "Respect for freedom of speech, print and publications guaranteed by the Constitution of PRL, and therefore no repressions of independent publications and access to mass media for representatives of all denominations" (Ash 1999:47). What is crucial the whole Polish democratic opposition supported the workers' demands. Those critical situations and the unfolding crisis in Poland become the matter of concern for Soviet government. The Kremlin started to insist on Polish political leaders to act more strikingly to stop strikes spreading all around Poland and to crush the Solidarity movement. At that time Politburo was preparing the plan of military action in Poland in case of further development of this dangerous social and political crisis. We have to remember that at those days around 66 thousand ${ }^{6}$ Soviet soldiers 


\section{SM̂PP}

were permanently stationed in Poland and other Red Army units were just outside of the borderline of the country. Other Warsaw Pact armies also surrounded Poland: Czechoslovakian and East German deployed military forces along Polish frontiers. Despite of mediation in which the Catholic Church was also involved political situation had become tenser. Among many economical demands those purely political occurred, like impossible to accept by contemporary communist authority claim for free elections and a referendum on general Wojciech Jaruzelski and his government (Paczkowski, Byrne 2007:31). That was one of the steps that pushed authorities to declare the martial law, which does not mean that earlier preparation for contingence had not been made. Membership of Solidarity grew up to 10 million people, which made this movement the biggest peaceful, nationwide, pro-democracy social organization in the whole socialistic block. The activity and successes of the movement created state of euphoria, this short period used to be called "Solidarity carnival". Prominent intellectuals, like Michel Foucault were fascinated by changes undergoing in Poland. All of this was stopped by introducing the martial state on the $13^{\text {th }}$ of December 1981 by a resolution of the Council of State adopted on the instruction of the Military Council of National Salvation. "According to available data, the operation involved about 70,000 soldiers, more than 30,000 Ministry of Internal Affairs functionaries, more than 40,000 reservists, 1,750 tanks, about 1,900 vehicles, more than 9,000 cars, several squadrons of cargo aircraft and helicopters and several score warships blockings access to ports"(Paczkowski, Byrne 2007:33). From the very first day of the martial law arrests, internment and interrogations were started. Their goal was to stop the leaders of the Solidarity movement but also the other broadly understood opposition. Soon about five thousand people were detained, and the total number of internees during the martial law amounted to 10 thousand 7 . The Code of Criminal Procedure was amended whereas the competences of military courts became expanded. Special units occupied striking factories. One of the most dramatic actions taken by military forces was the pacification of the "Wujek" mine causing as the result the deaths of nine miners. The liquidation of the printing house and distribution networks of the opposition press and the destruction of regional seats of Solidarity members also began on a large scale. These extraordinary and bloody events of the $13^{\text {th }}$ of December 1981 are well and bitterly described by Timothy Garton Ash. "In that freezing winter's night the Polish army and security forces invaded their own country. Tanks advanced into the centre of Warsaw. Troops set up roadblocks and between all major cities. Civilian telephone and telex lines were cut everywhere. Radio and television stations were taken over. Within hours Poland was partitioned and blockaded, internally and externally sealed off" (1999:273). This self-invasion caused shock among society, thousands of Solidarity activists went

7 https://ipn.gov.pl/ftp/13grudnia81/czytelnia/Stan_wojenny_Teka_edukacyjna.pdf [Accessed 16.02.2020] 
underground and continued their struggle. The martial law was suspended on the $31^{\text {st }}$ of December of 1982 and on the $22^{\text {nd }}$ of July of 1983 it was entirely cancelled. The introduction of the martial law was a severe and traumatic event for Polish people. Paweł Kaczmarczyk characterizes these events: "The temporary closure of borders due to the imposition of martial law only increased the migration potential, because the sense of helplessness and distrust of the system increased" (2005: 122). In addition, those outside the country at the time of the imposition of martial law were in equally hard position. "Some about 160.000 Polish citizens were abroad and now, at the stroke, found themselves in the position of forced exiles: for Solidarity activists, at least, return to Poland was out of question, others simply did not want to return. Temporary refugee camps were established, and from there Polish refugees spread out around the world (...)" (Łukaszewicz 2017:9). More similar cases will be further discussed in this article.

\section{Three variants of emigrant artists trajectories from the martial law period}

The material analyzed in this part of the article has been collected from over 60 narrative interviews conducted as a part of research on the contemporary emigration of Polish artists. They were carried out between 2008 and 2012 in four cities known for attracting not only Polish artists for decades. London, Paris, Berlin and New York are global cities, world capitals of art and culture, and frequent destinations for immigrant artists. The return to the material collected during the study results not only from the upcoming 40th anniversary of the introduction of martial law. The main motivation for re-analyzing the interviews, and more precisely, their fragments concerning this period, is the consequence of reflection on the phenomenon of forced emigration. Before discussing the empirical material, however, it is necessary to clarify the selection of the research group and the course of the analytical procedure. The participants of the study were artists living outside Poland. They all belonged to various generations, ranging from emigrants from World War II and ending with emigrants who left the country after Poland had joined the European Union. The deliberate sampling was based on two assumptions. First; seeking not only famous artists, those who have achieved success and who function well in the world of art, but also those who are recognized only in a narrow circle of recipients. It was supposed to widen the spectrum of researching the fate of Polish emigrant artists. The second assumption was that artists representing any field of art could become the participants of the research. Thus, the sample included painters, graphic artists, photographers, performers, filmmakers, musicians, sculptors, multimedia artists and writers. Recruitment was carried out mainly by the command method, snow-ball sampling, but also by direct search of respondents by the researcher. The collected interviews 
were subjected to sequential analysis, the purpose of which is "to reconstruct the form and structure of the reported life story, i.e. its temporary and thematic development during the interview" (Rosenthal 1990: 100). This analysis was to identify four basic biographical process structures distinguished by Fritz Schütze, which include: biographical action plans, trajectories, institutional formulas and biographical metamorphoses (2005: 306). The whole analytical undertaking was to lead to the reconstruction of the career paths of Polish artists who had found themselves in exile. In this case, the gaze was significantly narrowed, and thus attention was focused on the events of the early 1980s.

Among all the narratives gathered, the reference to the martial law as an important factor influencing the decision to emigrate or stay outside Poland appeared in eight cases. In a few other stories, however, a historical background was revealed as an accompanying factor, which did not significantly modify the emigration plans. The analysis of empirical material collected from evidences written down by representatives of Polish artistic emigration allows for the identification of three variants of biographical modification of plans as the immediate result of imposition of the martial law in Poland. In this case, the most important modifications of biographical plans were made under the influence of the events of December 1981. The first variant of this situation concerns people who were in Poland at the time of the declaration of the martial law and did not plan to leave the country permanently. In individual cases, various explanations of the reasons for emigration were revealed, which usually referred to socio-cultural and professional issues (limiting contacts with foreign artistic centres, no chances to develop a career, lack of access to European and world culture), economic (economic collapse of the country, inflation, supply shortages in stores) and political (restrictions on freedom of expression and movement, surveillance, threatening experiences of real and symbolic violence). The inability to carry out artistic projects in Poland freely and to continue further self-development was often mentioned in interviews. The desire to develop an artistic career in one's own country and the impact of the martial law are illustrated in the following fragment of the interview.

Back in 1980 when everything seemed possible and many things could have been done like never before or never again I saw my activity possible only in Poland but the martial law shut that all down (interview no 1, Paris, performer)

Political and economic situation in Poland led to emergence of a powerful incentive, especially for young artists, to seek prospects for improving living conditions and opportunities for developing an artistic career. Several respondents had suffered from limited contact with the world even before the martial law was imposed. In such cases negative social and cultural consequences of the martial law introduction were stressed most of all. In others the economic factor played the main role. 
This situation is well characterized by a fragment of the story of an artist living in New York. It also shows the perspective of a young artist and the biographical alternatives he would then see for himself. There are all sorts of reactions that the crisis can bring about, one of them is the readiness for a change. At this stage of shaping his biographical plans the respondent still considered to undertake circular emigration which was often mentioned in other biographical stories and was also often just a start to a permanent departure.

Departure in the summer of 1981 was an economic consequence (...) keep in mind that this background, of our lives, this situation that young people were in, young married couple, not to mention the rest of society, was fatal. Either you run away or you are becoming an alcoholic, or you give yourself a shot on the head because what perspectives did we have? That you get up and stay in line for three hours to get milk? That was our life, our conditions (...) nothing to wear, nothing to eat, no career either. I was 27 , I was ambitious, I wanted to do something with myself. So this decision to go the States came up, to do something and to return (interview no 2, New York, painter, graphic designer, illustrator).

As we may see, the biographical plan, repeatedly signalled in narratives, was based on the desire to undertake a temporary migration aimed at improving the economic situation. In the quoted fragment of the story, the narrator, justifying the reasons for his departure, refers to both millennium, discussing various family and environmental conditions, as well as historical factors, paying attention to the severe living conditions in Poland in the early 1980s. The narrator, like many others, facing no opportunities for the development of his artistic career or even earning chances, decided to leave. The introduction of the martial law often became an impulse to start thinking about emigration; it shaped biographically future plans and permanently changed the attitude towards one's own country. This happened in the case of the Berlin settled artist:

I decided to leave Poland on the $13^{\text {th }}$ of December of 1981; it was an easy and trivial situation. I was watching a movie by Taviani brothers St Michael had a rooster and the movie was interrupted at midnight so I went to sleep. In the morning Jaruzelski (announced the news) so my decision was: I am leaving this country, this country is not for me anymore, I was hurt like a child who wanted to change something in his environment and got rebuked. (interview no 3, Berlin, translator, writer, curator)

This specific, liminal biographical period in which the decision to leave was already made, without being able to move on to its effective implementation was mentioned in many of the analysed stories. Period of a biographical "suspension" was usually accompanied by a strong feeling of existential discomfort which in turn resulted from the lack of control over one's own fate. The reasons for this "suspension" varied and 


\section{SM̂PP}

their duration was also different. In addition to professional matters, which forced delay in the implementation of plans, such key factors were mentioned: family issues, the need to prepare the departure, being financially able. Political factors also played a very important role. One form of oppression often used by the PRL administration was the refusal to issue passports ${ }^{8}$. Passport policy has become a tool to fight and control the opposition by eliminating disturbing individuals associated with the opposition movement. Mieczysław Zlat who experienced this form of manipulation while he was deprived of liberty remembers this: "During these months of internment, I only had one conversation with the SB. I adopted the principle of not talking to them. This one time only in Nysa I was offered a passport and emigration naturally I refused" (2006: 246).

Obtaining a passport was extremely difficult, requiring many treatments and determination. After each arrival home the passport had to be returned to the office and one could not be sure whether the document would be issued again. There was also a specific type of passport, allowing only for a one-way trip or even allowing a travel only to the countries indicated. Descriptions of political repression, which should be considered a refusal to issue the passport, returned in many narratives.

(...) I was trying to get a passport for a couple of years and as a brother of a political dissident I was refused for seven years; then they gave me the one way passport that I could only leave the country with, to get rid of me which was simply convenient for them. The departure was gruesome in this way that my life story was given away, sold, apart from a few notebooks, a few things my parents left. I left by my tiny car, the Fiat that I got to leave and thus I arrived in Paris (interview no 4, Paris, painter, graphic designer, poster maker).

The above-mentioned fragment of the biographical story has all the traits of a trajectory experience, which included: dramatic circumstances of departure, the necessity to sell off the whole legacy, the inability to return to the country, uncertainty about the future, parting with loved ones. The government apparatus to get rid of unwanted people from the country used passport policy. The technique of manipulation and oppression consisted of, among others, the fact that initially for a certain period (even several years) the right to leave was refused in order to allow for a one-time crossing of the border. Such solution was a result from another oppressive strategy aimed at getting rid of persons non grata in the country. The unwanted or undesired, non grata individuals usually linked to the Solidarity underground were "suggested" to leave the country after they had suffered severe oppression from the security services. This is how Jan Sien, then the activist of the anti-communist opposition, today living in the US described it in an interview done by Andrzej Krajewski.

${ }^{8}$ This oppressive politics of the communist administration was widely elaborated by Dariusz Stola (2010). 
Esbecja (State security services) would make constant raids on my home, once or twice I ran away, but every time they had me they would always repeat that if I don't go from Poland for good, they would beat me, something will happen, I would be hit by a car. (1989: 147)

Vast majority of respondents never planned to leave Poland forever, but the consequences of repression escalating with the imposition of the martial law strengthened the sense of internal compulsion to leave their country. The excerpt below describes the method of oppression that was supposed to either make one leave Poland or collaborate with the services. For this reason the following quote shows also ethical dilemma:

I was trying to get a multiple passes passport but they would refuse me. They tried to threaten my friends, my mother; there was a burglary, everything upside down without anything stolen. My mother went to police but they said nothing stolen not our thing. So they read all mail, photographed all letters, this was what it looked like. It was not leaving Poland; it was Poland making me leave in a way I could not accept. This explained all these threatening and blackmailing all people around, refusing passports, which may have suggested that I collaborated with intelligence forces. There was no way to collaborate with the intelligence forces. Which meant: we let you go but when you return you are becoming an agent, our person. I did not want to accept my return on such terms. (interview no 5, New York, multimedia artist).

This fragment of the story once again describes the mechanism of repressing an individual by restricting freedom of moving around. The narrator, however, reveals significantly serious interventions of the state control apparatus, characteristic of the seventies and eighties - surveillance and intimidation, and finally attempts to get him involved in cooperation with communist intelligence services. In this case we are dealing with another experience of coercion; one can go in exchange for the collaboration. A firm rejection of such a proposal did not provide the respondent with a solution other than leaving Poland permanently. This is directly related to the biographical plan that the artist presents in the following way:

In a way this my leaving abroad was kind of my duty as an artist. Only few people could leave (...), in my case it was a mission, I was leaving with a sense of mission. The mission was to establish contacts with artists, with environment abroad so that to help to build some interesting program of good exhibitions in Foksal. I was like a consul, an emissary (...) I mean I made it finally and organized a couple of exhibitions of artists thanks to contacts that I obtained. Also the lectures, my mission was to speak loud about the situation in Poland in the context of what I valued and the environment. In some sense my being out of Poland was my duty as an artist. (interview no 5 New York, multimedia artist)

We can treat this situation as a yet another example of experiencing internal migration resulting from the way of perceiving one's social role and related tasks and the inability to implement them. Such a situation was not exceptional, the feeling 


\section{SM̂PP}

of having to leave the country is very often associated with the inability or significant limitation of the chances of implementing biographical plans. Respondents experienced various repressions of a different nature, including those described in the following excerpt from the interview:

We were staying within the area of iron curtain, I was not allowed to leave Poland for many years, I was forbidden to do my job, to teach, they interrogated me, they gave me ridiculous restrictions (interview no 3, Berlin, translator, writer, curator).

Thus, the imposition of the martial law caused readiness to emigrate, changing forever the life plans of many respondents. Not all of them could leave during duration of the martial law for administrative, political, often also family reasons, which is why their emigration began after the martial law had been cancelled. The urge to leave Poland would take the form of internal coercion, necessity resulting from disappointment, disagreement with political violence, pushing the country into a state of economic bankruptcy. The events of this period resonated so long and strongly in the respondents that many of them, even in the years post the martial law, did not change their emigration biographical plans.

Artists who happened to be outside Poland at the time the martial law was declared were in a different situation. This kind of traumatic experience happened to some of the study participants, but also to writer and playwright Janusz Głowacki. In December of 1981 he went to London to take part in rehearsals and the premiere of his play Cinders, staged at the Royal Court Theater. Głowacki described in his autobiographical book how he learned about the imposition of the martial law:

(...) on the $13^{\text {th }}$ of December, that very day when my fiancée at that time, Ewa was supposed to get on board of a plane at 8 o'clock, visit London, get herself some outfit and participate in the premiere, at 7 in the morning I was woken up by a call. My friend Nina Smolar was calling me with information that general Jaruzelski began a well-known to Polish readers action. (Głowacki 2004:7).

Deciding to stay in London Głowacki was not free from doubts if that was the right thing to do similarly to others who left their dear ones in the country. The suspension of flights to Poland gave Głowacki a few days to consider his situation and make a decision. Emotionally, however, it was an end full of anxiety:

(...) I was wandering around London, sometimes I met publishing agents, to each I was giving an interview and I was getting more and more anxious. The news from the country was terrible, the gossip even worse (...). And somewhere they're my little daughter with my mother and my fiancée. So what, return? Not to return? (Głowacki 2004:11).

To many the imposition of the martial law in Poland led to the final decision to stay abroad, although this was usually associated with serious dilemmas, lack 
of confidence and fear of the consequences of such a choice. This happened with a large group of Polish artists traveling to the USA to earn. The decision-making process was accompanied by numerous dilemmas and consultations with the family residing in the country, which often had a strong impact on respondents. This happened in the case of an artist who also found himself in New York during this period.

The summer is over, the fall is starting, time goes by when in Poland the martial law is introduced, on the $13^{\text {th }}$ of December the borders are closed, I get a service call from ZOMO and I ask my family: what to do? Do not come back. Do you understand? Do not come back. Stay there, do what you can, just do not come back. My wife says the same; do not come back. This is when I decide for a political asylum and in 1982 I am getting this asylum and here I am legally (interview no 2, New York, painter, graphic designer, illustrator).

In the next case similarly to the previous one, the decision to stay abroad was catalysed by a conflict with a close person who remained in Poland. The following excerpt also signals the dramatic problem of separation, which at the time of making the decision to stay abroad became temporarily indefinite. In many cases, as in the one cited below, lasting even several years.

I was leaving for three years to illustrate a book here in America. And the martial law came, and that was the main reason I stayed. I even wanted to come back [...]. I had a fiancée that I was in love with and it was obvious for me to go home. But then it turned out I had no ticket. Reagan suspended the flights, it was only possible through Canada and I had no money and that is how it ended. I got a letter from that fiancée, she told me not to return, to get her here instead because she was in health troubles. It lasted for three years but that was another story. But that is the main reason. I did not apply for asylum but being a known artist I applied for the privileges because it was humiliating to ask for the asylum as in that whole political mess and communist poverty I did not feel repressed. (interview no 8, New York, graphic designer, illustrator, inventor).

Imposition of the martial law influenced the fate of many Polish artists, often becoming a decisive factor for remaining outside Poland. In many cases, they were not planning long-term emigration. In this context, we can consider the martial law as an evident loss to Polish culture. The internal coercion felt by the respondents also resulted from a sense of deep exhaustion experiencing the protracted situation of oppression:

It was a temporary, very severe fatigue. But it did not make me ready for this; it was not planned, arranged, prepared, talked over. I just said: no, enough, I am tired. As soon as I can I am taking my son and I am leaving. I am not telling anybody I am just leaving. (interview no 7, Berlin, writer).

The third case of a reaction to the imposition of the martial law is a specific combination of the first and the second biographical situation. In the study it was 


\section{SM̂PP}

represented by one of narrators who stayed outside Poland in the moment of the martial law imposition. The artist left with a plan to recognize emigration opportunities. His surprise with the dramatic change in the situation in the country prompted him to return, but at the same time confirmed his belief in the need to leave Poland.

Then, maybe it was the night before the martial law, I tuned somehow a Russian radio station where they talked non-sense that in Poland they discovered arsenals of weapons, this all seemed to me so weird, then (...) the French media wrote about the beginning of the martial law (...). The question: what to do; to return to Poland and get my family here? We decided that yes, it is necessary to return first and to try to get out somehow from Poland. (Interview no 6, Paris, photographer).

The artist decided to return because of the family left in the country, but returning he already had a decision in mind to leave Poland again for good. During the martial law, it was not an easy decision and such an implementation required prior preparation. The return was associated with unpredictable consequences and the necessity of making efforts to leave the whole family. The three situations recurring in narrations, in fact, illustrate a similar social process that led to the creation of another Polish wave of emigration, which also included a large representation of artists. We can analyse this process in the categories proposed by Andrzej Piotrowski and Urlike Nagel: "escaping from" and "escaping to". Both categories are not so much an opposition as a kind of continuum. "Escape from" is an attempt to get out of the trajectory of suffering, while "escape to" is a consequence of the desire to get out of institutional coercion, from the need to meet expectations and it is a manifestation of the desire to self-plan your own biography (Waniek 2015: 35). Both motives are clearly revealed in the stories of Polish emigrant artists. On one hand, guided by a sense of internal coercion, they wanted to free themselves from the oppression of living under the martial law, on the other hand they sought to shape their fate independently, improve their own and their family living conditions, and actively influence career development. Therefore, they escaped from repression, poverty and restrictions, heading towards a democratic, free world. However, in many cases it was a journey into the unknown, the trips themselves took place in different conditions, often taking on a difficult, sometimes dramatic character.

\section{Conclusions}

The martial law in the narratives of the artists who left Poland proves to be a significant event affecting their biographical plans. As a rule, a strong trajectory component appeared in the stories of this period. In emigrant biographies one can indicate many moments of intense experience of the trajectory of suffering, both before leaving the home country and at the stage of settling and legalizing a stay in the new 
one. In both cases, these are oppressions of a different kind, of varying intensity, and different in their consequences, but always strongly determining the life of the individual. "The core of trajectory experience is the feeling of an individual that its fate is out of its will, inability to control it and act freely, in the peak phases bringing suffering, serious confusion and isolation from the world of others" (RokuszewskaPawełek 2002:79). Fritz Schütze describing a sequential structure of experiencing the trajectory writes that it is complex and multithreaded. This German sociologist distinguishes successive stages of trajectory experience, understood as biographical mechanisms of suffering development. At the initial stage, the trajectory potential accumulates. Schütze lists two decisive factors: a component of biographical dispositions to be hurt and a component of contradictions in the current life situation, for example difficulties in shaping personal life and everyday functioning (1997: 24-27). Artists subjected to censorship oppression and restrictions on the freedom to decide their own fate could experience both components. Often fragments of stories about this period showed trajectory, moments of alienation, confusion, uncertainty about the future, and often a strong longing for the family left in the country. In the conditions of the united Europe and untroubled movement between states, it is easy to forget how complicated the attempt to settle in a Western state was. A series of onerous administrative procedures, described by the artists from Berlin, London, Paris, and New York, could last even several years. The emigrants experienced various problems in virtually every sphere of their new life. One cannot forget about the adaptation and assimilation effort that had to be made and the necessity of struggling with the stigma of alienation. The consequences of emigration undertaken in this period were, among others: long-term parting with close relatives, inability to return to the country, breaking contact with the Polish artistic community, loss of a significant part of life's achievements (including artistic works). "Emigration means altered forms of existence, a break with the 'old' and a 'new' beginning, often it means the unbelievable and costly in the psychological sense difficulty of constituting oneself as an independent individual in a completely foreign and different world" (Dąbrowski 2001: 20). The hardship of starting a life outside one's own country, often associated with the drama of private, family or professional life, can be overcome, but it can also lead to the next stages of experiencing trajectories. Then what follows is destabilization, manifested in a sense of alienation towards oneself, lack of understanding of the actions taken, neglecting certain areas of life at the expense of others, which thus cease to be controlled.

In case of emigration resulting from the imposition of the martial law we can talk about its compulsory, trajectory character. Some respondents applied for a political asylum, which places them by definition in the category of forced migrants, expecting the refugee status (Castles, Miller 2011:234). Many respondents were leaving Poland with a sense of coercion, not agreeing to the then living conditions, limiting civic and creative freedom, at the same time declaring that they never wanted to 


\section{SM̂PP}

emigrate from Poland. It was the historical circumstances and not the desire to leave that forced them either to emigrate or to stay outside their home country. Formally, their cases often do not meet the definition criteria for classifying them as forced immigrants. Yet numerous fragments of collected biographical interviews clearly indicate a strong feeling of being urged to leave the country and long-term experience of various existential, political and economic inconveniences. Their decisions were not usually based solely on economic calculation, although what should be admitted, such motivation was not alien to them. When the economic situation of the country becomes extremely dramatic, departure appears as the only chance to improve the life situation and can be rationalized by the emigrant as forced one. When defining the forced migration, apart from the indication of objective factors triggering migration processes, it is also important to indicate this area, which subjectively generates a strong internal push impulse. The method of biographical interview makes it possible to recognize it, and indicates that, apart from external coercion, various weaves of circumstances, internally perceived suffering are revealed, which in some cases may lead to the decision to leave the home country.

\section{References}

Ash T.G. (1999), The Polish Revolution. Solidarity, New Haven and London: Yale University Press. Bobrowska-Jakubowska E. (2004), Artyści polscy we Francji w latach 1890-1918. Wspólnoty i indywidualności, Warszawa: Wydawnictwo DiG.

Castles S., Miller J.M. (2011), Migracje we współczesnym świecie, Warszawa: Wydawnictwo Naukowe PWN.

Czyżewski M. (1996), Generalne kierunki opracowania, wymiary analityczne, in: Czyżewski M.,Piotrowski A., Rokuszewska-Pawełek A. (eds.), Biografia a tożsamość narodowa, Łódź: Katedra Socjologii Kultury UŁ, pp. 45-51.

Dąbrowski M. (2001), Swój/Obcy/Inny. Z problemów interferencji i komunikacji międzykulturowej, Warszawa: Świat Literacki.

Głowacki J. (2004), Z głowy, Warszawa: Świat Książki.

Golka M. (2008), Socjologia sztuki, Warszawa: Wydawnictwo Difin.

Heinich N. (2007), Być artystą. Rzecz o przekształceniu statusu malarzy i rzeźbiarzy, Warszawa: VIZJA PRESS\&IT Ltd.

Kaczmarczyk P. (2005), Migracje zarobkowe Polaków w dobie przemian, Warszawa: Wydawnictwo Uniwersytetu Warszawskiego.

Krajewski M. (1989), Region USA. Działacze "Solidarności" o kraju, o emigracji, o sobie, Londyn: Wydawnictwo Aneks. Łukaszewicz S., Jaczyńska A., Pleskot P., (2017) Your Solidarity - Our Liberty. Reactions of emigre Poles and the world to the imposition of martial law in Poland on December 13th, 1981 (December 1981 - January 1982), Lublin-Warszawa.

Paczkowski A., Byrne M. (2007), The Polish Crisis: Internal and International Dimensions, in: Paczkowski A., Byrne M. (eds.), From Solidarity to Martial Law. The Polish Crisis of 1980-1981. A Documentary of History, Budapest, New York: Central University Press, pp. 1-43. 
Rokuszewska-Pawełek A. (2002), Chaos i przymus. Trajektorie wojenne Polaków - analiza biograficzna, Łódź: Wydawnictwo UŁ.

Rosenthal G. (1990), Rekonstrukcja historii życia, in: Włodarek J., Ziółkowski M. (eds.), Metoda biograficzna w socjologii, Warszawa: Wydawnictwo Naukowe PWN, 97-112.

Supruniuk A. (2006), Sztuka polska w Wielkiej Brytanii w latach 1940-2000, Źródła i stan badań, in: Supruniuk A. (ed.), Sztuka polska w Wielkiej Brytanii 1940-2000, seria Archiwum Emigracji, t. XXV, Toruń: Wydawnictwo UMK, pp. 5-22.

Schütz A. (2008), O wielości światów. Szkice z socjologii fenomenologicznej, Kraków: Zakład Wydawniczy NOMOS.

Schütze F. (2005), Cognitive Figures of Autobiographical Extempore Narration, in Miller R. (ed.) Biographical Research Methods, London: Sage Publications, pp. 289-338.

Schütze F. (1997), Trajektorie cierpienia jako przedmiot badań socjologii interpretatywnej, "Studia Socjologiczne", no. 1, pp. 11-57.

Stola D. (2010), Kraj bez wyjścia? Migracje z Polski 1949-1989, Instytut Pamięci Narodowej, Warszawa: Instytut Studiów Politycznych PAN.

Waniek K. (2015), "Ucieczka od" jako istotna przyczyna mobilności w Europie, "Folia Sociologica", no. 53, pp. $31-50$.

Zlat M. (2006), Od doradcy do "ujawnionego" konspiratora, in: Dudek A., Madej K. (eds.), Świadectwa stanu wojennego, Warszawa: Wydawnictwo IPN. 